\title{
IMPACTS OF SOLIDAGO GIGANTEA, PRUNUS SEROTINA, HERACLEUM MANTEGAZZIANUM AND FALLOPIA JAPONICA INVASIONS ON ECOSYSTEMS
}

\author{
KOUTIKA, L-S. ${ }^{1}{ }^{*}-$ RAINEY, H.J. ${ }^{2}-$ DASSONVILLE, N. ${ }^{3}$ \\ ${ }^{1}$ B.P. 4895, Pointe-Noire, Republic of the Congo \\ ${ }^{2}$ Wildlife Conservation Society, 2300 Southern Boulevard, 10460 Bronx, NY, USA \\ ${ }^{3}$ Laboratoire d'Ecologie Végétale et Biogéochimie. Université Libre de Bruxelles (ULB), \\ Boulevard du Triomphe (Campus Plaine, Bat BC, Local C5201), Bruxelles, Belgique \\ (phone: +242-813-34-52) \\ *Corresponding author \\ E-mail: ls_koutika@yahoo.com \\ (Received $3^{\text {rd }}$ September 2010 ; accepted $8^{\text {th }}$ February 2011)
}

\begin{abstract}
The world's biodiversity and ecosystems are threatened by the invasion of alien plant species. They have been found to impact the structure in function of ecosystems in temperate, tropical and subtropical areas (Holm et al., 1977; Pysek, 1997; Byers et al., 2002; Ehrenfeld, 2003). We reviewed studies to summarize the impact of four plant species invasions on European ecosystems: Solidago gigantea, Prunus serotina, Heracleum mantegazzianum and Fallopia japonica, because they are amongst a number of invasive species which have spread over the last centuries, and are still increasing their range in Europe. They cause negative impacts on both native biodiversity and ecosystem functioning (including productivity, nutrient cycling and soil organic matter dynamics).
\end{abstract}

Keywords: invasive plant species, natural and managed ecosystem, species effect, soil nutrients

\section{Introduction}

The spread of invasive alien plant species is an increasing concern in temperate (Pysek, 1998; Weber, 2001) as well as in subtropical and tropical areas (Holm et al., 1977; MacFadyen Cruttwell et al., 1996). An invasive plant species are species that adversely affect the habitats they invade economically, environmentally or ecologically. The majority of invaders reproduce by seed dispersal (Pysek, 1998), although an extremely successful minority relies exclusively on vegetative reproduction. The comparison between invasive and native plant species they displace has shown that invasive plant species tend to have a greater specific leaf area and higher nutrient concentrations in biomass and litter (Daehler, 2003; Ehrenfeld, 2003).

Invasive species can negatively impact native biodiversity and can be detrimental to economic interests as well as to public health, biodiversity; economic damage (Vitousek, 1997). Several authors: (Weber, 2001; Pairon et al., 2006; Vitousek et al., 1997; Byers et al., 2002; Ehrenfeld, 2003) have shown that invasion by an exotic or an alien plant is a serious threat to global biodiversity, severely affecting native species and communities. Range expansion of non-native alien species is likely to accelerate in response to global change (climate change, habitat modification, eutrophication, global transport), and has been described as one of the major threats to native communities (Maskell et al., 2006). Alien species invasions are often enhanced by anthropogenic disturbances (Hobbs and Huenneke, 1992). This may cause further changes to 
fundamental ecosystem processes in forests (MacMahon and Holl, 2001) and other ecosystems (Tickener et al., 2001; Weber, 2001; Ehrenfeld, 2003).

Some invasive species spread aggressively and their whole scale eradication may be difficult and have a high cost. To effect restoration of native plants their removal at specific sites is a necessary step. Eradication is especially important since the restoration process usually proceeds on a site-by-site basis across large area (Wiens et al., 1993). As human population and travel has increased the number of introductions of non-native alien organisms has increased in the past three centuries in both temperate (Weber, 2001) and tropical areas (Holm et al., 1977; MacMahon and Holl, 2001; Goodall and Erasmus, 1996).

Table 1. The four studied invasive plant species $(S g=$ Solidago gigantea $;$ Ps $=$ Prunus serotina; Hm = Heracleum mantegazzianum; Fj = Fallopia japonica)

\begin{tabular}{|c|c|c|c|c|c|}
\hline \multicolumn{2}{|c|}{ Species / Species variables } & \multirow{2}{*}{$\begin{array}{c}\text { Sg } \\
+ \\
+/-\end{array}$} & \multirow{2}{*}{$\begin{array}{l}\text { Ps } \\
+ \\
+\end{array}$} & \multirow{2}{*}{$\begin{array}{c}\text { Hm } \\
+\end{array}$} & \multirow{2}{*}{$\begin{array}{l}\mathbf{F j} \\
+\end{array}$} \\
\hline 1. Original use & $\begin{array}{c}\text { Ornamental use } \\
\text { Soil quality improvement }\end{array}$ & & & & \\
\hline $\begin{array}{l}\text { 2.Type of } \\
\text { vegetation }\end{array}$ & $\begin{array}{c}\text { Herb } \\
\text { Schrub } \\
\text { Tree }\end{array}$ & + & + & + & + \\
\hline \multicolumn{2}{|c|}{ 3. Rapid population growth } & + & + & + & + \\
\hline $\begin{array}{l}\text { 4. Mechanisms } \\
\text { of invasion }\end{array}$ & $\begin{array}{c}\text { Seeds } \\
\text { Vegetative reproduction }\end{array}$ & + & & + & + \\
\hline 5. Soil changes & $\begin{array}{c}\mathrm{pH} \\
\text { Nutrients } \\
\text { Soil fauna } \\
\text { Soil organic matter }\end{array}$ & $\begin{array}{l}- \\
+\end{array}$ & + & - & - \\
\hline \multicolumn{2}{|c|}{ 7. Impacts on biodiversity } & - & - & - & - \\
\hline \multicolumn{2}{|c|}{ 8. Economical impacts } & - & - & -- & --- \\
\hline \multicolumn{2}{|c|}{ 9. Impacts on public welfare } & $-/+$ & & --- & -- \\
\hline
\end{tabular}

There are general reviews on the effects of invasive exotic plant on soil nutrient cycling processes (Ehrenfeld, 2003; Levine et al., 2003). Dassonville et al. (2008) examined more specifically the impact of seven highly invasive plant species in North West Europe. Authors found that invaded plots had higher aboveground biomass and nutrient stocks in standing biomass compared to uninvaded resident vegetation, and concluded that the enhanced nutrient uptake may be a key trait of highly invasive plant species in Belgium. The authors also found that strong positive impacts (higher topsoil nutrient concentrations in invaded plots compared to uninvaded ones) were most often found in sites with initially low nutrient concentrations in the topsoil while negative impacts were generally found in the opposite conditions. The four plant species (Solidago gigantea, Prunus serotina, Heracleum mantegazzianum and Fallopia 
japonica) presented in this review are amongst those studied by (Dassonville et al., 2008), and amongst the more invasive species which have spread over Europe during the last centuries (Pysek, 1998; Weber, 2001; Dassonville et al., 2008), (Table 1). Their impacts are represented over the Europe.

\section{Impacts of Solidago gigantea invasions on ecosystems}

\section{Life history treats}

Solidago gigantea (Asteraceae) is a rhizomatous perennial herb native to North America and introduced into Europe about 250 years ago (Weber and Jacobs, 2005). The genus Solidago includes 100 species and almost all of these endemic to North America, although one species ( $S$. virgaurea) is native to Europe (Gleason and Conquist, 1991). S. gigantea is present both in wet and dry habitats and colonizes mainly disturbed areas such as roadsides, but fewer populations are found adjacent to rivers and lakes (Jacobs et al., 2004).

\section{Mechanism of invasion and ecosystem attribute that can be modified by S. gigantea}

After its introduction, S. gigantea has become widespread and has invaded a number of different ecosystems (Weber, 2001). Field survey results show increased growth performance of S. gigantea in its introduced range compared to conspecifics in their native range (Jacobs et al., 2004). Furthermore, Güsewell et al. (2006) found that S. gigantea often forms dense monospecific stands, eliminating all indigenous competitors in Europe, while in its native range, it is better integrated in diverse herbaceous vegetation. In fact, after comparison of 20 European (introduced) and 22 American (native) populations of S. gigantea (Güsewell et al., 2006) found that introduced S. gigantea populations tend to produce more shoots through clonal growth than the American native populations, even though there was no difference in shoots size and leaf traits. The authors argued that this may increase the ability of S. gigantea to compete against established species in dense stands or nutrient-poor sites. Meyer et al. (2005) tested the evolution of increased competitive ability hypothesis and found that European (introduced) S. gigantea are less resistant to American foliar pathogens and do not perform as well in the presence of insect herbivores as American (native) S. gigantea. Weber (2001) found evidence that strongly suggested that the spread of S. gigantea has not reached its limits and that its range expansion will continue. However the authors argued that $\mathrm{S}$. gigantea is confined to moist soils while $\mathrm{S}$. altissima which has spread less widely over Europe than S. gigantea, prefers drier sites, the latter might become more frequent along disturbed river banks and other moist soils (Weber, 2001).

\section{Changes in soil properties and nutrient contents}

Even though it is considered as an invasive species, $S$. gigantea may be used for environmental management in disturbed and contaminated areas. In an area where the chemical industry was active until 1999 in northern Italy, Vallino (2006) found that $S$. gigantea was the only plant able to counteract the severely harmful effects of industrial chemicals because of its arbuscular mycorrhizal fungi state. Arbuscular mycorrhizal fungi provide plants with mineral nutrients in exchange for carbon compounds and protect them against diverse abiotic and biotic stresses (Newsham et al., 1995). Vallino et al. (2006) also found a high density of arbuscular mycorrhizal fungi biodiversity in the cover soil of a hill. However, the authors argued that fungal presence 
and biodiversity did not seem to be the key factors that promote plant diversity at a recovering site.

Studies in Belgium demonstrated an impact of $S$. gigantea on soil properties and biogeochemical cycles. Vanderhoeven et al. (2006) found that nutrient stocks in aboveground biomass were twice as high in plots invaded by $S$. gigantea than in resident uninvaded vegetation. This suggests that $S$. gigantea might enhance nutrient uptake (especially phosphorus) mainly in topsoil $(0-10 \mathrm{~cm})$, since it does not root much deeper than the indigenous population. When considering soil phosphorus, ChapuisLardy et al. (2006) found that the plots invaded by $S$. gigantea generally had higher concentrations of labile $\mathrm{P}$ (resin extractable inorganic $\mathrm{P}$ and bicarbonate extractable and organic $\mathrm{P}$ ) than adjacent uninvaded soils. Furthermore soil $\mathrm{CO}_{2}$ production and alkaline and acid phosphormonoesterase activities were also higher, suggesting that the higher labile inorganic $\mathrm{P}$ concentration was due to enhanced mineralization. Additional studies have been made on soil $\mathrm{pH}$ and phosphorus fractions. Herr et al. (2007) showed that invaded plots had lower soil $\mathrm{pH}$ and $20-30 \%$ higher labile $\mathrm{P}$ fractions and this different remain consistent across seasons. This higher $\mathrm{P}$ availability in invaded soil could be due to the active acidification of the rhizosphere and/or by a rapid turnover of fine roots in winter (Herr et al., 2007). Study on soil organic matter status has shown high C contents of particulate organic matter fractions and a high soil $\mathrm{C}$ mineralization in soils colonized by $S$. gigantea compared to plots with native vegetation (Koutika et al., 2007).

\section{Impacts of Prunus serotina invasions on ecosystems}

\section{Life history treats}

Prunus serotina (Rosaceae) is native to eastern North America, and was first introduced in Europe in the $17^{\text {th }}$ Century as an ornamental tree. From the end of $19^{\text {th }}$ century onwards, $P$. serotina has been used in forestry as an auxiliary tree (e.g. Germany, the Netherlands and Belgium). P. serotina was widely cultivated in forest to improve soil quality and to prevent fire around pine plantations. As an indigenous species in North America, P. serotina may be dominated by other alien plant species [16]. The authors found that P. serotina was among the species which survived to Lonicera maackii, a nonindigenous shrub and invasive species, in plots where L. maackii was eradicated by cutting or by method using stem glyphosate injection.

\section{Mechanism of invasion and ecosystem attribute that can be modified by P. serotina}

$P$. serotina became invasive after its introduction and was called for long time "wood pest" (Lequercq, 1960). Currently P. serotina has spread across much of Europe i.e., from Denmark to Italy as well as from north France to Poland, Hungary and Rumania. This invasive plant species grows on sandy soil, but also grows on other soils from peaty to sandy.

To determine the factors controlling the abundance of $P$. serotina in the understory strata, Godefroid et al. (2005) conducted a study in Belgium and concluded that adoption of silvicultural system of irregular stands with mixed species with a dense canopy might hamper the development of $P$. serotina and allow a better conservation of indigenous forest species. The authors also argued that $P$. serotina shows a differential response to light intensity in relation to its development stage i.e., the species is heliophilous at the seedling stage and becomes a shade plant at the sapling stage. 
To determine the main factors explaining P. serotina invasive success in Belgium, (Pairon et al., 2006) analysed flowering fruit production, seed rain, dispersal and viability and survival of seedling at different ages and individuals in pine plantations. The authors found that fruit production was high (up to 8,940 fruits per tree) as trees produced huge quantities of flowers, while both flower and fruit production were highly variable between years and among individuals. Furthermore, using a stochastic stagestructured population model to describe the dynamics of $P$. serotina in northern France, (Sebert-Cuvillier et al., 2007) studied the local demographic explosion of a species in a suitable stand where it had initially established. However the model could not predict the further spread of the species in the surrounding forest landscape.

\section{Changes in soil properties and nutrient contents}

Reinhart et al. (2003) used the plant soil biota interactions and spatial distribution of $P$. serotina in its native and invasive ranges, and presented evidence showing that, in its native range, the soil community that develops in the rhizosphere of $P$. serotina inhibits the establishment of neighbouring conspecifics and reduce the performance of seedlings in greenhouse. In contrast in its introduced range, $P$. serotina readily establishes in close proximity to conspecifics, while the soil community enhances the growth of the seedlings. Reinhart et al. (2003) suggested that $P$. serotina may have escaped the direct negative effects of host-specific soil pathogens and its growth is facilitated by the soil community in its introduced range while being inhibited by the soil community in its native range. However the authors used the 'whole soil' inoculum, which tests the net effect of the soil community on survival and growth of $P$. serotina and did not test for the specific effect of soil pathogens on seedling establishment.

Koutika et al. (2007) evaluated soil organic matter dynamics under P. serotina stands in Belgium and found high $\mathrm{C}$ contents of particulate organic matter fractions and high soil C mineralization in P. serotina invaded areas. However, the authors argued that since soil texture was different at non-invaded and invaded sites in two out of three sites, changes occurring after $P$. serotina invasion might not be solely due to exotic plant invasion. Dassonville et al. (2008) also found that P. serotina tends to increase the $\mathrm{pH}$ of invaded soils.

\section{Impacts of Heracleum mantegazzianum invasions on ecosystems}

\section{Life history treats}

Heracleum mantegazzianum (Apiceae) is a Caucasian species invasive in Europe, which is regularly listed in global overviews of noxious invasive species (MacMahon and Holl, 2001; Vallino et al., 2006; Weber, 2004). H. mantegazzianum was introduced to the British Isles as a garden plant during the $19^{\text {th }}$ century, and has since become widespread, particularly along rivers and waterways (Collingham et al., 2000). Other species of Heracleum were introduced into Europe from South East Asia in the $19^{\text {th }}$ century, and are now also widespread in many countries. H. mantegazzianum (otherwise known as giant hogweed) has long been recognized as a prominent example of an invasive alien with a wide distribution, significant impact and remarkable dynamics of spread in Europe (Nielsen et al., 2005). 
Mechanism of invasion and ecosystem attribute that can be modified by H. mantegazzianum

H. mantegazzianum has higher gene flow between the invasive species ranges, possibly due to more frequent independent introductions (Jahodova, 2007). H. mantegazzianum does not reproduce vegetatively, but only by seeds (Pysek and Pysek, 1995; Tiley et al., 1996). Moravcovà et al. (2005) found that $90 \%$ of H. mantegazzianum seeds germinated regardless of the vigour of the mother plant or where it was produced on the plant. The authors concluded that the high fecundity and opportunistic behaviour associated with high percentages of germination of coldstratified seed, as well as high seed production compared to other species (Pysek and Pysek, 1995; Tiley et al., 1996), may account for the successful invasion of H. mantegazzianum in Central Europe, where the species has negative effects on biodiversity, the economy and public health.

Using aerial photographs from 11 sampling dates between 1947 (before H. mantegazzianum invasion started) and 2000, Müllerovà et al. (2005) found that pastures and fields contributed $84.7 \%$ to Heracleum total cover, forest and shrub $13.7 \%$ and human settlements $1.6 \%$ at later stages of invasion. The authors found that as invasion proceeded, the populations spread from linear habitats to the surrounding landscape with the mean rate of aerial spread of $1,261 \mathrm{~m}^{2}$ per year and linear spread of $10.8 \mathrm{~m}$ per year. The authors also argued that knowledge of rate of spread and habitat vulnerability to invasion facilitates the identification of areas at highest risk of immediate invasion.

Using an individual-based modelling technique, Nehrbass and Winkler (2007) illustrated that the invasion status of $H$. mantegazzianum and found that populations are still expanding in space. Moreover, the authors found that although the long term average population growth rate is larger than that of native species and populations generally expand, there are years in which populations of invasive species declined (actual growth rate $\mathrm{R}<1$ ). The authors were able to validate their statistical data on local dynamics of $H$. mantegazzianum and estimated the long-term development of the examined populations of $H$. mantegazzianum to characterize invasive behaviour of the species. Short term empirical observations recorded decreasing individual numbers of the species and the deterministic matrix model approach. This result has been used and projected as future development. Furthermore, Nehrbass and Winkler (2007) found that $H$. mantegazzianum is still an invasive species, but choice of sampling site and date may lead to large variations in results of invasive potential. Analysis of the model results showed that more than a third of the invasive populations could have an annual growth rate below one.

\section{Changes in soil properties and nutrient content}

Considering soil mineral element composition of invasive species (including H. mantegazzianum), Vanderhoeven et al. (2005) found an increase of concentrations of exchangeable essential nutrients under the canopy of exotic invasive plants mainly for $\mathrm{K}$ and $\mathrm{Mn}$ compared to native species. The authors concluded that their results fit in well with reports of an enhancement of $\mathrm{N}$ dynamics in invaded sites, probably due to higher primary productivity in exotic invasive plants compared to native vegetation. Koutika et al. (2007) showed that the soils under the plots invaded by H. mantegazzianum had lower particulate organic matter weight (POM), $\mathrm{C}$ and $\mathrm{N}$ 
contents and $\mathrm{C}$ mineralization. The authors suggested that soil organic matter dynamics slow in the plots invaded by $H$. mantegazzianum.

\section{Impacts of Fallopia japonica invasions on ecosystems}

\section{Life history treats}

The genus Fallopia (Polygonaceae) contains c. 24 species world wide of which seven are considered weeds, among them Fallopia japonica var. japonica (Houdt), the most invasive clone (Bailey, 1994). Fallopia japonica is a rhizomatous dioecious perennial (geophyte) native to Japan, Korea and Taïwan. In its native areas $F$. japonica grows in sunny places on hills, high mountains, road verges and ditches, river gravels and managed pastures on wide range of soils from sea level to $2400 \mathrm{~m}$ a.s.l. (Child and Wade, 2000). F. japonica was introduced into Europe as an ornamental plant in the 1820 s and spread exponentially throughout Europe during the 1900s on disturbed areas, roadsides, and river banks via accidental transport of rhizome fragments (Sheppard et al., 2005).

The Fallopia species are invasive throughout the temperate world including much of North America and more recently Australia. They are on the IUCN 100 worst invasive species list, are the second most damaging alien plant in Germany (land holder poll) and are amongst the top 10 invasive plant species in France and UK (Bailey, 1994; Manchester and Bullock, 2000). In these countries F. japonica var japonica is one of three species recognised as having significant impacts on biodiversity (Manchester and Bullock, 2000). The species increase risk of flooding and the deep rhizomes hinder construction projects and cause physical damage to drainage structures, building foundations and road surface (Beerling, 1991). Shaw and Seiger (2002) believe that biological control is the only long-term, sustainable solution to Fallopia species.

\section{Mechanism of invasion and ecosystem attribute that can be modified by F. japonica}

$F$. japonica forms dense stands that prevent other species from growing (Pysek, 1998). Tickener et al. (2001) argued that relatively little research has been undertaken on competitive interactions between alien and native riparian plant species such as Fallopia or Heracleum. The authors also observed that with the increase of biological invasion, riparian habitats which are considered to be particularly prone to invasion by alien plants, have been the focus of most studies.

\section{Changes in soil properties and nutrient contents}

Kappes et al. (2007) evaluated the impact of Fallopia on soil dwelling fauna and concluded that the structure of the soil fauna shifted from a plant-based to detritus-based food chain. The Fallopia invasion also benefits predators that profit from his simplified vegetation structure. Therefore, Gerber et al. (2008) showed that riparian habitats invaded by Fallopia_support lower number of plant species and lower overall abundance and morphospecies richness of invertebrates as compared to native grassland and bush habitats. The authors also found that the biomass of invertebrates in bush was almost twice as high as that in Fallopia_invaded habitats. Finally Gerber et al. (2008) concluded that large-scale invasion by exotic Fallopia species is therefore likely to seriously affect biodiversity and reduce the quality of riparian ecosystems for amphibians, reptiles, birds and mammals whose diets are largely composed of arthropods. 
Soil organic matter status has been evaluated in plots invaded by $F$. japonica invasion compared to plots with native vegetation in the central Belgium (Koutika et al., 2007). The authors showed the changes in soil organic matter status through a reduction of soil organic matter (lower particulate organic matter weight and $\mathrm{C}$ and $\mathrm{N}$ contents and lower $\mathrm{C}$ mineralization) in the invaded fields compared to fields under the native vegetation. Dassonville et al. (2007) examined the impacts of Fallopia on topsoil chemistry and nutrient stocks. They found that soils under Fallopia generally had higher exchangeable nutrient concentrations $(\mathrm{Cu}, \mathrm{K}, \mathrm{Mg}, \mathrm{P}$ and $\mathrm{Zn})$ compared to soils under native vegetation. Standing biomass was 3 to 13-fold higher depending on site, and 4-5fold larger nutrient stocks in aboveground biomass of Fallopia were found. According to Dassonville et al. (2007), the higher nutrient concentration in soil invaded by $F$. japonica could be explained by a nutrient uplift mechanism (sensu Jobbagy and Jackson, 2004).

\section{Conclusions}

We reviewed the literature to investigate four plant species which are amongst a number of invasive species which have spread over the last centuries, and are still increasing their range in Europe: Solidago gigantea, Prunus serotina, Heracleum mantegazzianum and Fallopia japonica. We can conclude that for all the four species: (i) Invasive expansion is continuing (ii) the four plant species are threats to biodiversity of natural and managed ecosystems; and (iii) Solidago gigantea, Prunus serotina and Fallopia japonica do not have a direct negative impact on public health, but Heracleum mantegazzianum is dangerous to humans.

The invasion mechanisms of both $S$. gigantea and $F$. japonica are quite similar, i.e. $S$. gigantea often forms dense monospecfic stands, eliminating all indigenous competitors (Güsewell et al., 2006), while $F$. japonica forms as well dense stands that prevent other species from growing (Pysek, 1998). The invasion mechanisms of $P$. serotina and $H$. mantegazzianum differ from those of $S$. gigantea and $F$. Japonica. In fact, the invasion mechanisms of $P$. serotina and $H$. mantegazzianum have some similarities in fruit seed production but $H$. mantegazzianum is more fecund and P. serotina has more flowers (Pairon et al., 2006; Pysek and Pysek, 1995; Tiley et al., 1996).

Three major characteristics of the impact of the four species on soil properties are: (i) the invasion of $S$. gigantea induces changes in soil properties mainly in the topsoil (0-10 $\mathrm{cm})$ compared to the soils under the native vegetation, i.e., increased phosphorus availability (Chapuis-Lardy et al., 2006; Herr et al., 2007; Vanderhoeven et al., 2005; Vanderhoeven et al., 2006), and changes in soil organic matter dynamics mainly in active particulate organic matter and C respiration (Koutika et al., 2007); (ii) after invasion by $P$. serotina, soil properties change compared to soil under the native vegetation with an increase of $\mathrm{C}$ in particulate organic matter fraction and $\mathrm{C}$ respiration in the topsoil (Koutika et al., 2007); (iii) in contrast to the other two species, the invasions of $H$. mantegazzianum and $F$. japonica reduced the soil $\mathrm{C}$ respiration and created soil organic matter which decomposed slowly (Koutika et al., 2007).

Acknowledgements. Authors thank Hervé Rouhier (Université Catholique de Louvain, Belgium) for providing some scientific papers which allow the writing up of this review paper. 


\section{REFERENCES}

[1] Bailey, J.P. (1994): Reproductive biology and Fertility of Fallopia japonica (Japanese knotweed) and its hybrids in the British Isles. - In: de Wall, L.C, Child, L.E., Wade, P.M. \& Brock J.H. (eds.) The Ecology and Management of invasive riverside plants, John Wiley and sons, Chichester, UK.

[2] Beerling, D.J. (1991): The testing of concrete revetment blocks resistant to growths of Rey noutria japonica_(Japanese knotweed) - Water Resources 24: 495-498.

[3] Byers, J.E., Reichard, S., Randal, J.M., Parker, I.M., Smith, C.S., Lonsdale, W.M., Atkinson, I.A.E., Seastedt, T.R., Williamson, M., Chornesky, E., Hayes, D. (2002): Directing research to reduce the impacts of non indigenous species. - Conservation Biology 16: 630-640.

[4] Chapuis-Lardy, L., Vanderhoeven, S., Dassonville, N., Koutika, L.S., Meerts, P. (2006): The effects of the exotic invasive plant Solidago gigantea on soil phosphorus. - Biology and Fertility of Soils: 42, 481-489.

[5] Child, L.E., Wade, P.M. (2000): The japanese knotweed. - Manual, Packard Publishing, Chichester, UK.

[6] Collingham, Y.C., Wadsworth, R.A., Huntley, B., Hulme, P.E. (2000): Predicting the spatial distribution of non-indigenous riparian weeds: issues of spatial scale and extent. Journal of Applied Ecology 37: 313-327.

[7] Daehler, C.C. (2003): Performance comparisons of co-occurring native and alien invasive plants: implications for conservation and restoration. - Annual Revue Ecological Systems 34: $183-211$.

[8] Dassonville, N., Vanderhoeven, S., Gruber, W., Meerts, P. (2007): Invasion by Fallopia japonica increases topsoil mineral nutrient concentrations. - Ecoscience 14(2): 230-240.

[9] Dassonville, N., Vanderhoeven, S., Vanparys, V., Hayez, M., Gruber, W., Meerts, P. (2008): Impacts of alien invasive plants on soil nutrients are correlated with initial site conditions in NW Europe. - Oecologia 157: 131-140.

[10] Ehrenfeld, F.G. (2003): Effects of Exotic plant Invasions on Soil Nutrient Cycling Processes. - Ecosystems 6: 503-523.

[11] Gerber, E., Krebs, C., Murell, C., Moretti, M., Rocklin, R., Schaffner, U. (2008): Exotic invasive knotweeds (Fallopia spp) negatively affect native plant and invertebrate assemblages in European riparian habitats. - Biological Conservation. doi: 10/ 1016/j.biocon.2007.12.009.

[12] Gleason, H.A., Conquist, A. (1991): Manual of vascular plants of Northeastern United States and adjacent Canada. $-2^{\text {nd }}$ edn. New York Botanical Garden, Bronx.

[13] Godefroid, S., Singh Phartyal, S., Weyembergh, G. (2005): Ecological factors controlling the abundance of non-native black cherry (Prunus serotina) in deciduous forest understory in Belgium. - Forest Ecology \& Management 210: 91-105.

[14] Goodall, J.M., Erasmus, D.J. (1996): Review of the status and integrated control of the invasive alien weed, Chromolaena odorata in South Africa. - Agriculture, Ecosystems \& Environment 56: 151-164.

[15] Güsewell, S., Jacobs, G., Weber, E. (2006): Native and introduced populations of Solidago gigantea differ in shoot production but not in leaf traits or litter decomposition. - Functional Ecology 20: 575-584.

[16] Hartman, K.M., McCarthy, B.C. (2004): Restoration of forest understory after the removal of an invasive shrub, Armur Honeysuckle (Lonicera maackii). - Restoration Ecology 12(2): 154-165.

[17] Herr, C., Chapuis-Lardy, L., Dassonville, N., Vanderhoeven, S., Meerts, P. (2007): Seasonal effect of exotic invasive plant Solidago gigantea on soil $\mathrm{pH}$ and $\mathrm{P}$ fractions. Journal of Plant Nutrition \& Soil Science 170: 729-738. 
[18] Hobbs, R.J., Huenneke, L.K., (1992): Disturbance, diversity and invasion: implications for conservation. - Conservation Biology 6: 324-337.

[19] Holm, L.G., Plucknett, D.L., Pancho, J.V., Herberger, J.P. (1977): The world's worst weeds distribution and Biology. - University Press of Hawaii, Honolulu.

[20] Jacobs, G., Weber, E., Edwards, P.J. (2004): Introduced plants of the invasive Solidago gigantea (Asteraceae) are larger and grow denser than conspecifics in the native range. Diversity \& Distributions 10: 11-19.

[21] Jahodova, S., Trybush, S., Pysek, P., Wade, M., Karp, A., (2007): Invasive species of Heracleum in Europe: an insight into genetic relationships and history. - Diversity \& Distributions 13: 99-114.

[22] Jobbagy, E.G., Jackson, R.N. (2004): The uplift of soil nutrients by plants: Biogeochemical consequences across scales. - Ecology 85: 2380-2389.

[23] Kappes, H., Lay, R., Topp, W. (2007): Changes in different trophic levels of letterdwelling. Macrofauna associated with Giant knotweed invasion. - Ecosystems 10: 734744.

[24] Koutika, L-S., Vanderhoeven, S., Chapuis-Lardy, L., Dassonville, N., Meerts, P. (2007): Assessment of changes in soil organic matter following invasion by exotic plant species. - Biology and Fertility of Soils 44: 331-341.

[25] Lequercq, W.L. (1960): Dennenmoorder en Prunus serotina. Nederlands Bosbouwtijaschrift 32: 74-75. (cited in Godefroid et al. 2005).

[26] Levine, J.M., Vila, M., D’Antonio, C., Dukes, J.S., Grigulis, K., Lavorel, S. (2003): Mechanisms underlying the impacts of exotic plant invasions. - Proceedings of the Royal Society of London, Biological Science 270: 775-781.

[27] MacFadyen Cruttwell, R.E., Skarratt, B. (1996): Potential distribution of Chromolaena odorata (siam weed) in Australia, Africa and Oceania. - Agriculture Ecosystems \& Environment 59: 89-96.

[28] MacMahon, J.A., Holl, K.D. (2001): Ecological restoration: a key to conservation biology's future. - In: Soulé, M.F., Orians, G.H. (eds.). Conservation Biology: research priorities for next decade . Island Press. Washington D.C.

[29] Manchester, S.J., Bullock, J.M. (2000): The impacts of non-native species on UK biodiversity and the effectiveness of control. - Journal of Applied Ecology 37: 845-864.

[30] Maskell, L.C., Firbank, L.G., Thompson, K., Bullock, J.M., Smart, S.M. (2006): Interactions between non-native plant species and the floristic composition of common habitats. - Journal of Ecology 94: 1052-1060.

[31] Meyer, G., Clare, R., Weber, E. (2005): An experimental test of evolution of increased competitive ability hypothesis in goldenrod Solidago gigantea. - Oecologia, 144: 299307.

[32] Moravcovà, L., Perglovà, I., Pysek, P., Jarosk, V., Pergl, J. (2005): Effects of fruit mass a,d seed germination in the alien species Heracleum mantegazzianum (Apiceae) and the implications of its invasion. - Acta Oecologia 28: 1-10.

[33] Müllerovà, J., Pysek, P., Vojtech, J., Pergl, J. (2005): Aerial photographs as a tool for assessing the regional dynamics of invasive plant species Heracleum mantegazzianum. Journal of Applied Ecology 42: 1042-1053.

[34] Nehrbass, N., Winkler, E. (2007): Is the giant Hogweed still a threat? An individualbased modelling approach for local invasion dynamics of Heracleum mantegazzianum. Ecological Modelling 201: 377-384.

[35] Newsham, K.K., Fitter, A.H., Watkinson, A.R. (1995): Multifunctionality and Biodiversity in arbuscular mycorrhizas. - Trends in Ecology \& Evolotion 10: 407-411.

[36] Nielsen, C., Ravn, H.P., Nentwig, W., Wade, M. (2005): The giant hogweed best practice manual. Guidelines for the management and control of an invasive weed in Europe. Forest and Landscape Denmark, Horsholm, Denmark. 
[37] Pairon, M., Chabrerie, O., Mainer, C., Jacquemart, A.L. (2006): Sexual regeneration traits linked to black cherry (Prunus serotina Ehrh) invasiveness. - Acta Oecologia 30: 238247.

[38] Pysek, P. (1997): Clonality and plant invasions: can a trait make a difference? - In: de Kroon, H.V.A., Groenendael, J. (eds). The Ecology and Evolution of clonal Plants. Backhuys Publishers, Leiden pp 405-427.

[39] Pysek, P. (1998): Alien and native species in Central European urban floras: a quantitative comparison. - Journal of Biogeography 25: 155-163.

[40] Pysek, P., Pysek, A. (1995): Invasion by Heracleum mantegazzianum in different habitats in The Czech Republic. - Journal of Vegetable Science 6: 711-718.

[41] Reinhart, K.O., Packer, A., van der Putten, W.H., Clay K. (2003): Plant soil Biota interactions and spatial distributions of black cherry in its native and invasive ranges. Ecology Letters 6: 1046-1050.

[42] Sebert-Cuvillier, E., Paccaut, F., Chabrerie, O., Endels, P., Goubuc, O., Decocq, G. (2007): Local population dynamics of invasive tree species with a complex life-history cycle: A stochastic matrix model. - Ecology Modelling 201: 127-143.

[43] Shaw, R.H., Seiger, L.A. (2002): Japanese knotweed. - In: Van R., Driesch B., Blossey M., Hoddle S., Lyom \& Reardon R. (eds). Biological control of invasive plants in the Eastern United States, 159-166. Forest Health Technology Enterprise Team, Morgantown, WV, USA.

[44] Sheppard, A.W., Shaw, R.H., Sforza, R. (2005): Environmental weeds for classical biological control in Europe: a review of opportunities regulations and other barriers to adoption. - Weed Research 46: 93-117.

[45] Tickener, D.P., Angold, P.G., Gurnell, A.M., Mountford, J.O. (2001): Riparian plant invasion: hydrogeomorphological control and ecological impacts progress. - Physical geography 25(1): 22-52.

[46] Tiley, G.E.D., Dodd, F.S., Wade, P.M. (1996): Biological flora of the British Isles. 190. Heracleum mantegazzianum Sommier et Levier. - Journal of Ecology 84: 297-319.

[47] Vallino, M., Massa, N., Lumini, E., Bianciotto, V., Berta, G., Bonfante, P. (2006): Assessment of arbuscular mycorrhizal fungi diversity in roots of $S$. gigantea growing in a polluted soil in northern Italy. - Environmental Microbiology 8(6): 976-983.

[48] Vanderhoeven, S., Dassonville, N., Chapuis-Lardy, L., Hayes, M., Meerts, P. (2006): Impact of invasive alien plant Solidago on primary production, plant nutrient and soil mineral nutrient concentrations. - Plant \& Soil 286: 259-268.

[49] Vanderhoeven, S., Dassonville, N., Meerts, P. (2005): Increased topsoil mineral nutrient concentrations under exotic invasive plants in Belgium. - Plant and Soil 275 (1-2): 169179.

[50] Vitousek, P.M., D’Antonia, C.M. Loope, L.L., Rejmanek, M., Westbrooks, R. (1997): Introduced species: a significant component of human-caused global change. - New Zealand Journal of Ecology 21: 1-16.

[51] Weber, E. (2001): Current and potential ranges of three exotic golden rods (Solidago) in Europe. - Conservation Biology 15: 122-128.

[52] Weber, E. (2004): Invasive plant species of the World: a reference Guide to Environmental weeds. - CABI Publishers, Wallingford.

[53] Weber, E., Jacobs, G. (2005): Biological flora of central Europe: Solidago gigantea Aiton. - Flora 200: 109-118.

[54] Wiens, J.A., Stenseth, N.C., Van Horne, B., Ims, R.A. (1993): Ecological mechanisms and landscape ecology. - Oikos 66: 369-380. 